\title{
Efficiency of applying urea and UTEC carbamide on rice crops
}

\author{
Askhad Sheudzhen ${ }^{1,2}$, Tatyana Bondareva ${ }^{1,2 *}$, Oksana Gutorova ${ }^{2}$, and Pshimaf Khachmamuk ${ }^{1}$ \\ ${ }^{1}$ Federal Scientific Rice Centre, Krasnodar, Russia \\ ${ }^{2}$ Kuban State Agrarian University, Krasnodar, Russia
}

\begin{abstract}
The high efficiency of UTEC carbamide (modified NBPT - N(n-butyl) thiophosphoric triamide carbamide) is experimentally proven basing on analysis of the dynamics of the ammonium nitrogen content in the meadow soil of rice irrigation systems of Krasnodar region and the urease activity, the nitrogen consumption by rice plants, yield, nitrogen yield removal and its utilization from fertilizer. Different schemes of applying nitrogen fertilizer are assessed. It is shown that when applying nitrogen fertilizer at a full rate in one step, it is necessary to give preference to UTEC carbamide; with fractional UTEC application, it is advisable to apply before sowing and as top dressing in germination phase, the second UTEC carbamide fertilization is less effective than that with urea; with a $20 \%$ reduction in the UTEC carbamide application rate, a yield comparable to that under the traditional scheme and rate of urea application is formed; the greatest ecological and agrochemical effect is achieved with the following fertilization system: before sowing - ammophos $100 \mathrm{~kg} / \mathrm{ha}\left(\mathrm{N}_{12} \mathrm{P}_{52}\right)+$ UTEC carbamide $120 \mathrm{~kg} / \mathrm{ha}$ ( $\mathrm{N}_{55}$ ); 1st top dressing (germination) - UTEC carbamide $100 \mathrm{~kg} / \mathrm{ha}\left(\mathrm{N}_{46}\right)$; 2nd top dressing (tillering) - urea $80 \mathrm{~kg} / \mathrm{ha}$ ( $\mathrm{N}_{37}$ ).
\end{abstract}

\section{Introduction}

The most effective means of increasing rice yields are mineral fertilizers, especially nitrogen fertilizers. However, only $20-40 \%$ of nitrogen applied is used by rice plants. Significant losses of nitrogen lead not only to a decrease in the efficiency of fertilizers, but also to environmental pollution due to volatilization of ammonia, migration of nitrates and nitrites with irrigation water into the waste network and groundwater. Losses of $\mathrm{NH}_{3}$ from urea are on average 10-19\% [1], but at high air temperatures during the period of its application, they can reach $40 \%$ [2,3]. The $\mathrm{NH}_{3}$ loss is reduced by the immediate incorporation of the fertilizer into the soil either mechanically or by flooding the rice field. In Krasnodar region, it is not always possible to do this immediately after the urea application, mostly due to weather conditions and the supply of irrigation water to the rice irrigation system. An alternative way to reduce $\mathrm{N}$ losses is to slow down the hydrolysis of urea by temporarily blocking soil urease [4]. A large number of substances that inhibit urease have been identified [5-10].

\footnotetext{
* Corresponding author: bondarevatatjna@mail.ru
} 
EuroChem has registered urease inhibitor NBPT (N-(N-butyl) thiophosphoric triamide) with the commercial name UTEC. We have studied its influence on the development of plants and the productivity of rice agrocenosis. An increase in the rice plants supply with nitrogen and in coefficient of its utilization from fertilizer with the introduction of UTEC carbamide in comparison with urea has been established [11]. This indicates the need to adjust the $\mathrm{N}$ fertilization rate when applying UTEC carbamide. The results of studying this issue are presented in this article.

\section{Methods}

The studies were carried out for the ecological and agrochemical assessment of the modified UTEC carbamide and the development of an optimal scheme for its use in the rice fertilization system, which ensures the optimization of mineral nutrition of plants and the reduction of nitrogen losses in fertilizers.

Experimental data were obtained in a field experiment (2018-2020) conducted in accordance with generally accepted methods on a rice irrigation system located in the Central agro-climatic zone of Krasnodar region. The soil of the experimental plot is meadow lightloamy. It is characterized by the following agrochemical indicators: the total humus content $3.0 \%$, total nitrogen $-0.218 \%$, mobile forms of phosphorus $\left(\mathrm{P}_{2} \mathrm{O}_{5}\right)$ and potassium $\left(\mathrm{K}_{2} \mathrm{O}\right)$, 26.8-27.0 and $291 \mathrm{mg} / \mathrm{kg}$ respectively, $\mathrm{pH}_{\text {water }}-6.47-6.55$ units, $\mathrm{pH}_{\mathrm{KCl}}-5.2$ units.

Plot area $-850 \mathrm{~m}^{2}$; 4-fold repetition; placement of variants is randomized; predecessor - rice; seeding rate of 7 million germinating grains per hectare; irrigation regime shortened flooding. Rice cultivation techniques are recommended by Federal Scientific Rice Centre for this zone. Variants: 1. No fertilizers [control]; 2. Before sowing ammophos $100 \mathrm{~kg} / \mathrm{ha}\left(\mathrm{N}_{12} \mathrm{P}_{52}\right)+$ urea $120 \mathrm{~kg} / \mathrm{ha}\left(\mathrm{N}_{55}\right)$, 1-st top dressing (germination) urea $100 \mathrm{~kg} / \mathrm{ha}\left(\mathrm{N}_{46}\right)$, 2-nd top dressing (tillering) - urea $80 \mathrm{~kg} / \mathrm{ha}\left(\mathrm{N}_{37}\right)$ [standard]; 3. Before sowing - ammophos $100 \mathrm{~kg} / \mathrm{ha}\left(\mathrm{N}_{12} \mathrm{P}_{52}\right)+$ urea $300 \mathrm{~kg} / \mathrm{ha}\left(\mathrm{N}_{138}\right)$; 4. Before sowing - ammophos $100 \mathrm{~kg} / \mathrm{ha}\left(\mathrm{N}_{12} \mathrm{P}_{52}\right)+$ UTEC carbamide $225 \mathrm{~kg} / \mathrm{ha}\left(\mathrm{N}_{104}\right) ; 5$. Before sowing ammophos $100 \mathrm{~kg} / \mathrm{ha}\left(\mathrm{N}_{12} \mathrm{P}_{52}\right)$, 1-st top-dressing (germination) - urea $150 \mathrm{~kg} / \mathrm{ha}\left(\mathrm{N}_{69}\right)$, 2nd top dressing (tillering) - urea $150 \mathrm{~kg} / \mathrm{ha}\left(\mathrm{N}_{69}\right) ; 6$. Before sowing - ammophos $100 \mathrm{~kg} / \mathrm{ha}$ $\left(\mathrm{N}_{12} \mathrm{P}_{52}\right)$, 1-st top dressing (germination) - UTEC carbamide $150 \mathrm{~kg} / \mathrm{ha}\left(\mathrm{N}_{69}\right)$, 2-nd top dressing (tillering) -UTEC carbamide $150 \mathrm{~kg} / \mathrm{ha}\left(\mathrm{N}_{69}\right)$; 7. Before sowing - ammophos 100 $\mathrm{kg} / \mathrm{ha}\left(\mathrm{N}_{12} \mathrm{P}_{52}\right)$, 1-st top dressing (germination) - UTEC carbamide $112 \mathrm{~kg} / \mathrm{ha}\left(\mathrm{N}_{52}\right)$, 2-nd top dressing (tillering) -UTEC carbamide $113 \mathrm{~kg} / \mathrm{ha}\left(\mathrm{N}_{52}\right)$; 8. Before sowing - ammophos $100 \mathrm{~kg} / \mathrm{ha}\left(\mathrm{N}_{12} \mathrm{P}_{52}\right)+$ UTEC carbamide $150 \mathrm{~kg} / \mathrm{ha}\left(\mathrm{N}_{69}\right)$, 1-st top dressing (germination) UTEC carbamide $150 \mathrm{~kg} / \mathrm{ha}\left(\mathrm{N}_{69}\right)$; 9 . Before sowing - ammophos $100 \mathrm{~kg} / \mathrm{ha}\left(\mathrm{N}_{12} \mathrm{P}_{52}\right)+$ UTEC carbamide $112 \mathrm{~kg} / \mathrm{ha}\left(\mathrm{N}_{52}\right)$, 1-st top dressing (germination) -UTEC carbamide $113 \mathrm{~kg} / \mathrm{ha}\left(\mathrm{N}_{52}\right)$; 10 . Before sowing - ammophos $100 \mathrm{~kg} / \mathrm{ha}\left(\mathrm{N}_{12} \mathrm{P}_{52}\right)+$ UTEC carbamide $120 \mathrm{~kg} / \mathrm{ha}\left(\mathrm{N}_{55}\right)$, 1-st top dressing (germination) -UTEC carbamide $100 \mathrm{~kg} / \mathrm{ha}\left(\mathrm{N}_{46}\right)$, 2-nd top dressing (tillering) - urea $80 \mathrm{~kg} / \mathrm{ha}\left(\mathrm{N}_{37}\right)$; 11. Before sowing - ammophos $100 \mathrm{~kg} / \mathrm{ha}$ $\left(\mathrm{N}_{12} \mathrm{P}_{52}\right)+$ UTEC carbamide $90 \mathrm{~kg} / \mathrm{ha}\left(\mathrm{N}_{41}\right)$, 1-st top dressing (germination) - UTEC carbamide $75 \mathrm{~kg} / \mathrm{ha}\left(\mathrm{N}_{35}\right)$, 2-nd top dressing (tillering) - urea $60 \mathrm{~kg} / \mathrm{ha}\left(\mathrm{N}_{28}\right)$. In all variants of the experiment, before sowing, ammophos was applied at the rate of $\mathrm{N}_{12} \mathrm{P}_{52}$. The selection of plants was carried out in germination phase, 7 days after the 1st (tillering) and 2nd (booting) top dressings, ear emergence phase and full grain ripeness. The soil for agrochemical analysis was sampled before sowing, in germination phase, 7 days after the 1st top dressing, 7 days after the 2nd top dressing, after harvesting.

Soil moisture was determined by gravimetric method, $\mathrm{pH}_{\text {water }}$ by potentiometric method, the exchange-absorbed ammonium content in the soil - in a $2 \% \mathrm{KCl}$ solution according to Kudeyarov [12], the urease activity in the soil - according to Galstyan [13], nitrogen in 
plants - according to Kjeldahl (GOST 13496.4-93). Statistical evaluation of the research results was carried out using the analysis of variance [14].

Weather conditions during the years of research were favorable for the growth and development of rice plants.

\section{Results and discussion}

The dynamics of the exchange-absorbed ammonium content in the soil is determined by its redox regime. The restored conditions occurring after the soil flooding contributed to an increase in its amount from $1.24 \mathrm{mg} / 100 \mathrm{~g}$ of soil to 1.63 in the control and 2.29$2.96 \mathrm{mg} / 100 \mathrm{~g}$ when fertilizing. This is due to both the supply of nitrogen with fertilization and the redistribution of nitrogen forms: a reduction in nitrate form and the appearance of ammonium form. The greatest amount of ammonium nitrogen in the soil is observed in the phase of rice germination, then it gradually decreases. After the discharge of water from the rice field, the ammonium nitrogen content in the soil decreases sharply, which is associated with losses with waste and filtration waters and a change in redox conditions that cause the oxidation of ammonium compounds and nitrogen transition to other forms. After rice harvesting, the ammonium nitrogen content in the soil decreased by 1.5-2.5 times compared to rice germination phase. Such dynamics of ammonium nitrogen in the soil was observed in all the years of our research both in the control and with the application of fertilizers (Fig. 1).
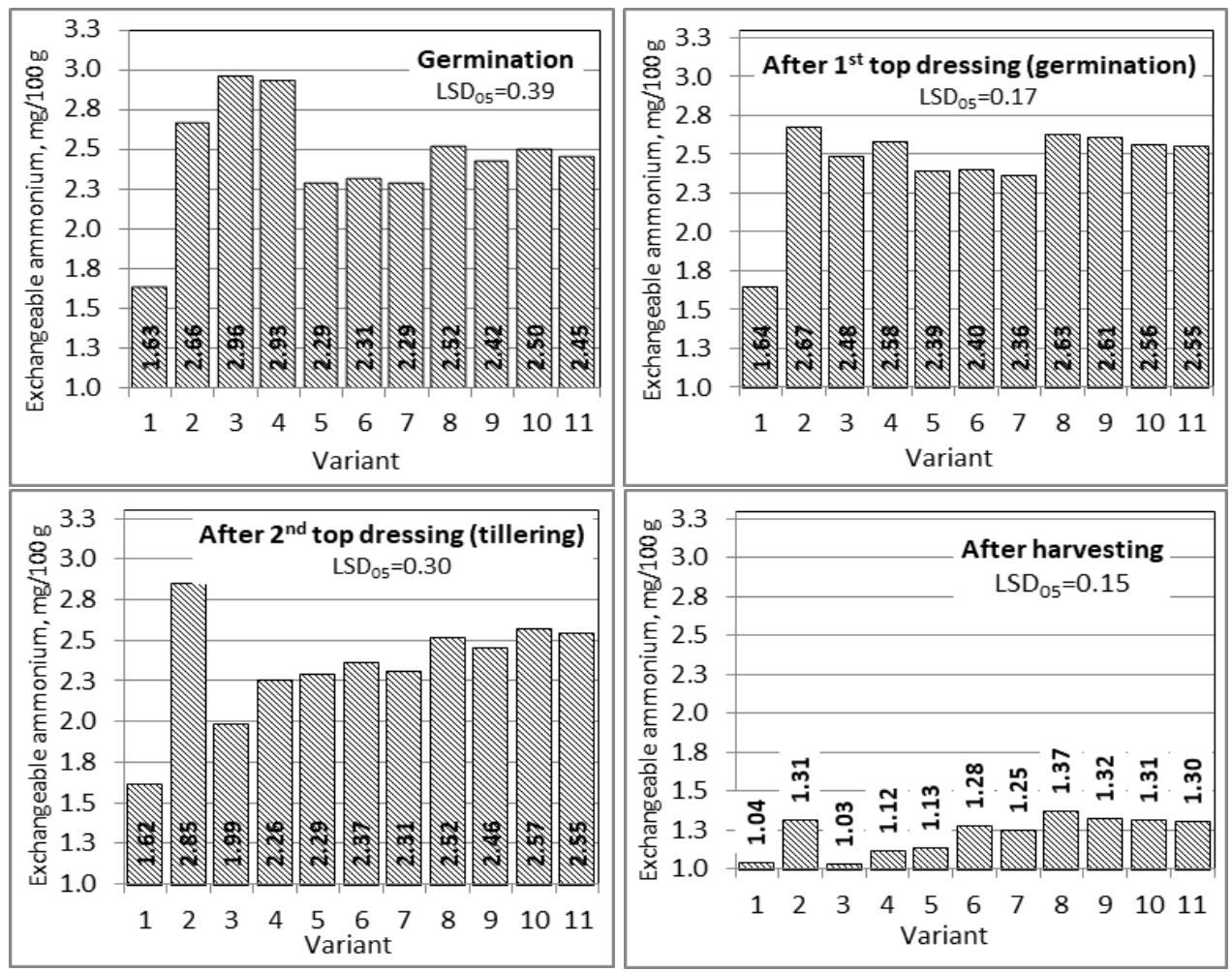

Fig. 1. Dynamics of exchangeable ammonium content in soil. Variants $1-11$.

When applying urea and UTEC carbamide in one step before sowing, already in the tillering phase, the soil contained less ammonium nitrogen than with other schemes. Moreover, its smallest amount was noted when using ordinary urea for fertilization (variant 
3). At the same time, when UTEC carbamide was applied in one dose, even in a $25 \%$ lower rate (variant 4), ammonium nitrogen content in soil was higher.

Top dressing of rice crops with nitrogen fertilizers during the germination and tillering phases had a different effect on the dynamics of exchangeable ammonium content in the soil. When applying UTEC carbamide before sowing and in first top dressing and urea in the second, rice plants were provided with nitrogen to a greater extent throughout ontogenesis (versions 10,11). The variants with application of nitrogen fertilizers in two doses - in the germination and tillering phases (variants 5-7) and before sowing and in tillering phase (variants 8-9) - did not differ significantly from these variants in terms of the ammonium nitrogen content in the soil. There were no significant differences when reducing the UTEC application rate by $25 \%$.

Urea hydrolysis in soils, catalyzed by urease, is a quick process accompanied by the consumption of protons. As a consequence, the $\mathrm{pH}$ of the soil should increase. Overrein L.N. and Moe P.G. observed an increase in soil pH from 6.5 to 8.8 [cit. by 15]. We did not notice a significant change in the reaction of the soil solution. After flooding the soil under rice, the $\mathrm{pH}$ value increased from 6.56 to 6.66-6.74 units in germination phase, or by $0.10-0.18$ units. (Fig. 2). The fertilizers applied as top dressing slightly acidified the soil solution, which is more pronounced after the first top dressing. On variants with the application of the full rate of fertilizers before sowing, the $\mathrm{pH}$ values are slightly higher and more stable over time. After the rice was harvested, the $\mathrm{pH}$ of the soil environment decreased, which is associated with improved soil aeration and, consequently, the oxidation of reduced compounds.
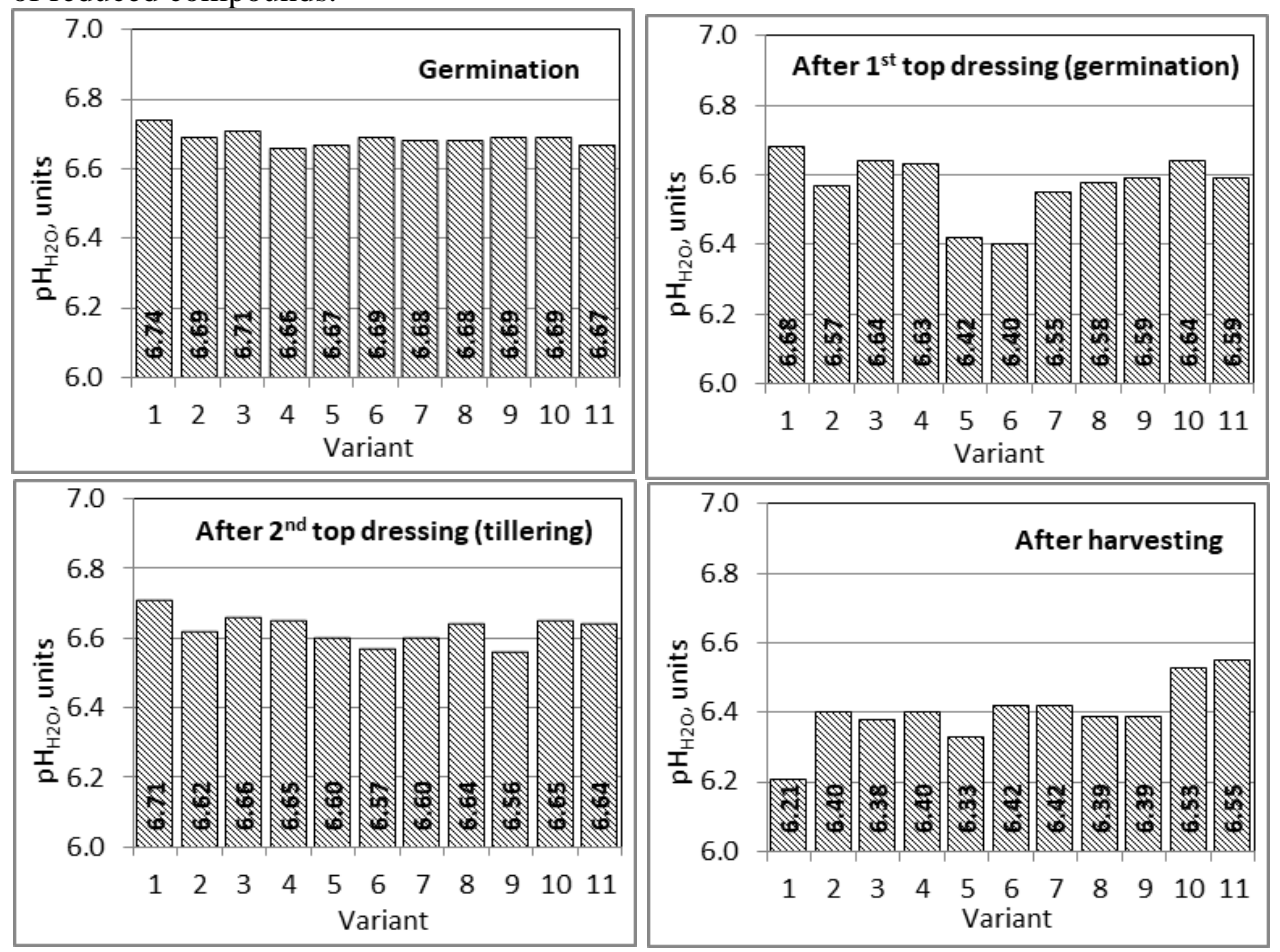

Fig. 2. Change in soil environment reaction

Urease hydrolyzes urea to ammonia and carbon dioxide. In the soil, urea is formed during the conversion of nitrogenous organic compounds - proteins and nucleic acids. In significant quantities, it is applied with manure and in the form of concentrated nitrogen fertilizer. $\mathrm{NH}_{3}$ formed as a result of the urease reaction serves as a source of nitrogen 
nutrition for plants [16]. According to the degree of urease enrichment, the soil of the experimental plot is classified as poor (according to Zvyagintsev [17]). Before rice sowing, the urease activity in it was $3.34 \mathrm{mg} \mathrm{NH}_{3} / 10 \mathrm{~g} / 24 \mathrm{~h}$ (Fig. 3).

Flooding of the rice field soil and the resulting restored conditions increased the urease activity. The lowest enzyme activity, very poor by the Zvyagintsev scale, was noted in the control without the use of fertilizers (2.12-300 $\mathrm{mg} \mathrm{NH}_{3} / 10 \mathrm{~g} / 24 \mathrm{~h}$ ). After top dressing with nitrogen fertilizers in rice plants germination and tillering phases, the urease activity increased and was 1.5-2.0 times higher than that in the control. This was especially evident when applying UTEC carbamide before sowing and in germination phase and urea in tillering (var. $10-11$ ), where its activity after the 1 st top dressing increased by $14.3-16.9 \%$ and remained quite high after the second. The urease activity is lower with top dressing only with urea in the classical form. In comparison with other variants, the activity of this enzyme increased by 3$9 \%$, which indicates more intense ammonification processes in the soil.
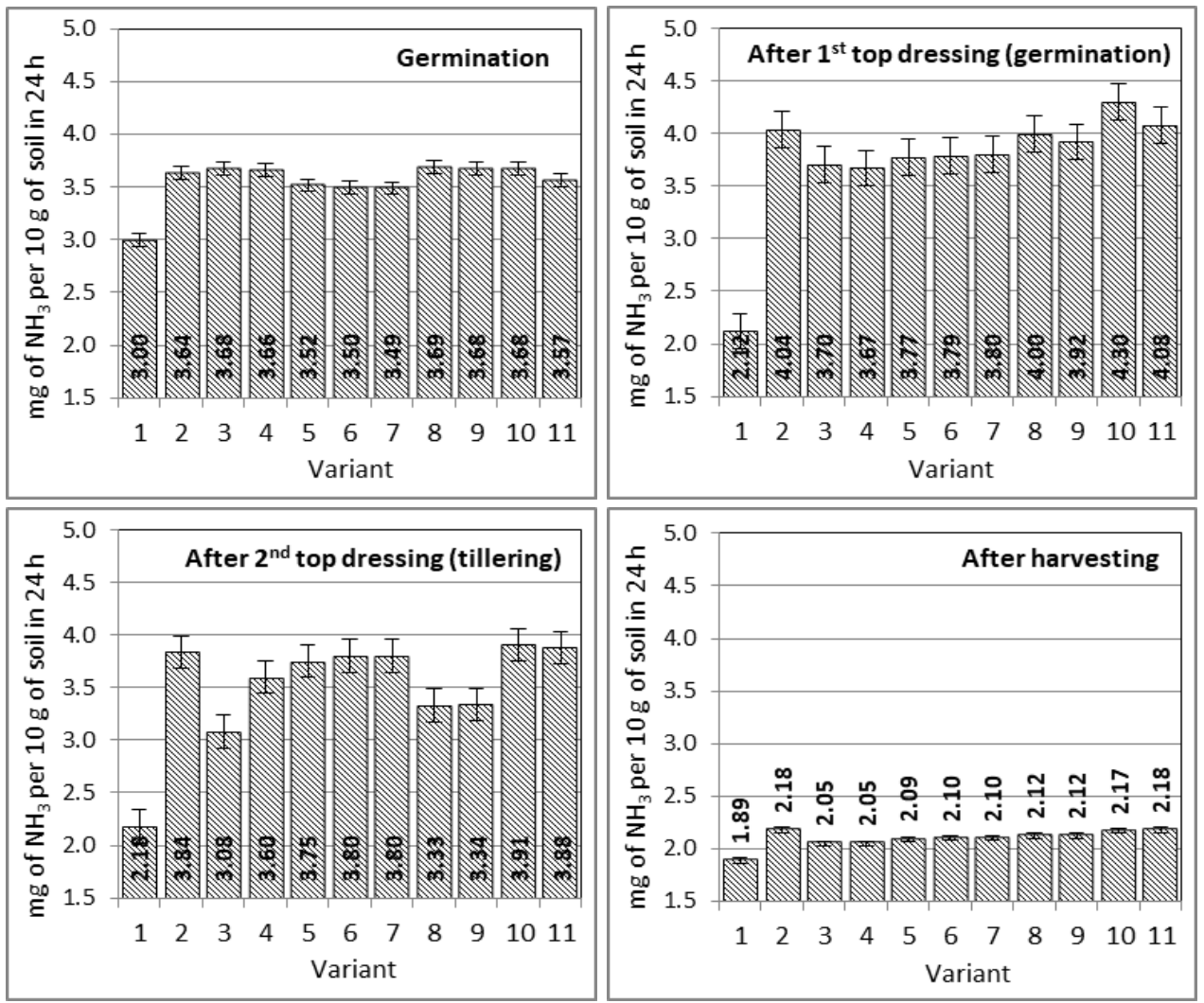

Fig. 3. Urease activity in soil.

In variants with the application of the full urea rate before sowing (variant 3), the urease activity increased in the germination phase and sharply decreased in tillering. The same tendency was revealed after the 1st UTEC carbamide top dressing (variant 8). With application of UTEC carbamide in one dose reduced by $25 \%$ rate (variant 4 ), such a reaction was not observed.

Nitrogen fertilization in three doses - before sowing + top dressing in germination phase with UTEC carbamide and in tillering with urea (variants 10,11) favorably influenced the nitrogen regime and the enzymatic activity of the soil. After top dressing, ammonium nitrogen content and urease activity in these variants were the highest in the experiment. 
The highest nitrogen content in rice plants was observed during germination phase. In the process of their growth, its amount in the vegetative organs gradually decreases. Before the ear emergence stage, this is associated with an intensive increase in the mass of plants, and during the grain filling period - with the attraction of elements to the generative organs. The application of fertilizers does not change the noted dynamics of the content of these elements in plants, but is reflected in the quantitative indicators of this process.

The most significant differences in nitrogen content in plants were noted in rice germination phase. The amount of this element in plants from fertilized agrocenoses exceeded those in control plants by 1.04-1.76\% (Table 1). However, plants growing with a full rate applied before sowing (variants 3 and 4) and when applying UTEC carbamide before sowing at the rate of $\mathrm{N}_{69}, \mathrm{~N}_{55}, \mathrm{~N}_{52}$ and $\mathrm{N}_{41}$ (variants 8-11) had nitrogen content higher than that of agrocenosis with traditional scheme of urea application.

Table 1. Nitrogen content in rice plants when applying UTEC carbamide, dry mass \%.

\begin{tabular}{|c|c|c|c|c|c|c|}
\hline \multirow{3}{*}{ Variant } & \multicolumn{6}{|c|}{ Vegetation phase } \\
\hline & \multirow[b]{2}{*}{ germination } & \multirow[b]{2}{*}{ tillering } & \multirow[b]{2}{*}{ booting } & \multirow[b]{2}{*}{$\begin{array}{c}\text { ear } \\
\text { emergence }\end{array}$} & \multicolumn{2}{|c|}{ full ripeness } \\
\hline & & & & & $\begin{array}{c}\text { leaves + } \\
\text { stems }\end{array}$ & grain \\
\hline 1 & 1.43 & 1.36 & 1.30 & 1.09 & 0.51 & 0.64 \\
\hline 2 & 2.85 & 2.64 & 2.34 & 2.04 & 0.95 & 1.18 \\
\hline 3 & 3.19 & 2.82 & 2.12 & 2.00 & 1.00 & 1.14 \\
\hline 4 & 3.18 & 3.05 & 2.40 & 2.17 & 0.83 & 1.22 \\
\hline 5 & 2.47 & 2.42 & 2.40 & 2.03 & 0.67 & 1.20 \\
\hline 6 & 2.48 & 2.55 & 2.42 & 2.12 & 0.66 & 1.21 \\
\hline 7 & 2.46 & 2.54 & 2.41 & 1.79 & 0.61 & 1.18 \\
\hline 8 & 3.15 & 2.94 & 2.40 & 1.96 & 0.72 & 1.12 \\
\hline 9 & 3.06 & 2.93 & 2.38 & 1.88 & 0.78 & 1.11 \\
\hline 10 & 3.12 & 2.83 & 2.64 & 2.22 & 0.73 & 1.21 \\
\hline 11 & 3.00 & 2.62 & 2.64 & 2.20 & 0.69 & 1.21 \\
\hline
\end{tabular}

The nitrogen content in rice plants was influenced not only by the rates and timing, but also by the form of fertilization. When the whole rate of urea and UTEC carbamide was applied in one dose, the rice plants in the tillering phase contained the largest amount of nitrogen in the experiment - by $0.33-0.34 \%$ more than in the traditional (variant 2) scheme of applying nitrogen fertilizers. In the tillering phase, the advantage of UTEC carbamide slightly increases, while that of urea decreases. In the booting phase, the plants from the variant with urea (variant 3 ) contained $0.22 \%$ less nitrogen, and with UTEC (variant 4 ) - by $0.06 \%$ more than with the traditional scheme of nitrogen fertilization. These differences persisted in the emergence and full ripeness (in grain) phases. Based on these data, it can be argued that the loss of nitrogen from urea is greater than that from UTEC, which causes a deficiency of this element in the soil.

When applying nitrogen fertilizers in two doses - in the germination and tillering phases (variants 5-7), - at the beginning of ontogenesis (seed germination - seedlings) the plants are less supplied with nitrogen than in the traditional scheme (variant 2), which manifested itself in a lower content of the element in plants. By the tillering phase, these differences were reduced, and during booting, they completely disappeared. In ear emergence phase, the plants from the variants with the application of $300 \mathrm{~kg} / \mathrm{ha}$ of urea (variant 5) and 225 $\mathrm{kg} / \mathrm{ha}$ UTEC (variant 7) contained less nitrogen than those from the variant with the traditional scheme. An insignificant nitrogen deficiency in the first case is most likely due to the loss of the element, and in the second - an insufficient rate. When applying $300 \mathrm{~kg} / \mathrm{ha}$ of UTEC carbamide in two doses, the rice plants accumulated more nitrogen. 
When applying 300 (var. 8) and $225 \mathrm{~kg} / \mathrm{ha}$ (var. 9) UTEC carbamide in two doses before sowing and in germination phase - the nitrogen deficiency for plants was indicated in emergence phase. If these rate of nitrogen fertilizers were applied in three doses (var. 1011 ), and for the application before sowing and in germination phase, UTEC was used, and urea - in the tillering phase, rice plants were better supplied with nitrogen throughout the growing season.

Application of nitrogen fertilizers provided an increase in rice yield by $20.8-64.6 \%$. The replacement of urea by UTEC is accompanied by an increase in rice yields. With the application of the entire rate of nitrogen fertilizer before sowing rice, a significant increase in yield compared to the traditional scheme was not revealed. On the contrary, it decreased by $0.7 \mathrm{t} / \mathrm{ha}$ or $10.8 \%$ with the application of urea and by $0.1 \mathrm{t} / \mathrm{ha}(1.5 \%)$ - with UTEC, which is insignificant (Table 2).

Table 2. Rice yield when applying nitrogen fertilizers, yield removal of nitrogen and phosphorus and the efficiency of their utilization by plants.

\begin{tabular}{|c|c|c|c|c|c|c|c|}
\hline & \multirow{2}{*}{ Variant } & \multicolumn{2}{|c|}{$\begin{array}{c}\text { Yield, } \\
\text { t/ha }\end{array}$} & \multicolumn{2}{|c|}{$\begin{array}{c}\text { Amount used for } \\
\text { formation of } 1 \text { centner } \\
\text { of grain, kg }\end{array}$} & \multicolumn{2}{c|}{$\begin{array}{c}\text { Coefficient of } \\
\text { utilization from } \\
\text { fertilizers, \% }\end{array}$} \\
\cline { 3 - 8 } & & $\begin{array}{c}\text { nitrogen } \\
(\mathrm{N})\end{array}$ & $\begin{array}{c}\text { phospho- } \\
\text { rous } \\
\left(\mathrm{P}_{2} \mathrm{O}_{5}\right)\end{array}$ & $\begin{array}{c}\text { nitrogen } \\
(\mathrm{N})\end{array}$ & $\begin{array}{c}\text { phosphoro } \\
\text { us }\left(\mathrm{P}_{2} \mathrm{O}_{5}\right)\end{array}$ & $\begin{array}{c}\text { nitrogen } \\
(\mathrm{N})\end{array}$ & $\begin{array}{c}\text { phospho- } \\
\text { rous } \\
\left(\mathrm{P}_{2} \mathrm{O}_{5}\right)\end{array}$ \\
\hline 1 & 4.8 & 45.31 & 32.11 & 0.94 & 0.67 & - & - \\
\hline 2 & 6.5 & 113.47 & 52.70 & 1.75 & 0.81 & 45.4 & 39.6 \\
\hline 3 & 5.8 & 100.72 & 43.22 & 1.74 & 0.75 & 36.9 & 21.4 \\
\hline 4 & 6.4 & 109.70 & 49.45 & 1.71 & 0.77 & 55.5 & 33.3 \\
\hline 5 & 6.4 & 102.33 & 48.31 & 1.60 & 0.75 & 38.0 & 31.2 \\
\hline 6 & 6.9 & 110.62 & 51.41 & 1.60 & 0.75 & 43.5 & 37.1 \\
\hline 7 & 6.8 & 104.95 & 52.29 & 1.54 & 0.77 & 51.4 & 38.8 \\
\hline 8 & 7.2 & 111.53 & 56.51 & 1.55 & 0.78 & 57.1 & 46.9 \\
\hline 9 & 7.2 & 113.38 & 55.93 & 1.57 & 0.78 & 58.7 & 45.8 \\
\hline 10 & 7.9 & 129.97 & 63.76 & 1.65 & 0.81 & 56.4 & 60.9 \\
\hline 11 & 7.6 & 123.22 & 61.49 & 1.62 & 0.81 & 67.2 & 56.5 \\
\hline LSD & 0.36 & & & & & & \\
\hline
\end{tabular}

Rice yield with urea application at the rate of $300 \mathrm{~kg} / \mathrm{ha}$ in two steps (variant 5) - in the germination and tillering phases - did not differ significantly from that of the standard variant. If UTEC carbamide was applied according to this scheme at the same rate (variant 6), the yield increased by $0.4 \mathrm{t} / \mathrm{ha}$ or $6.2 \%$, and even with a reduction in the rate by $25 \%$ (variant 7 ), the yield was higher by 0.3 t/ha (4.6\%). With application of UTEC before sowing and in germination phase, the yield increased by $0.7 \mathrm{t} / \mathrm{ha}(10.8 \%)$ both at the rate of $300 \mathrm{~kg} / \mathrm{ha}$ and $225 \mathrm{~kg} / \mathrm{ha}$.

The highest yield was formed when nitrogen fertilizer was applied in three doses UTEC carbamide before sowing and in germination phase, and urea in tillering phase. With this scheme of nitrogen fertilization, it is higher than with the traditional one by $1.4 \mathrm{t} / \mathrm{ha}$ (21.5\%) at a rate of $300 \mathrm{~kg} / \mathrm{ha}$ and $1.1 \mathrm{t} / \mathrm{ha}(16.9 \%)-225 \mathrm{~kg} / \mathrm{ha}$.

Yield removal of nutrients and their amount for the grain formation characterize the efficiency of fertilizers utilization. Yield removal of nitrogen significantly increased only with a threefold application of nitrogen fertilizer - UTEC carbamide before sowing and top dressing in germination phase and urea top dressing in tillering phase. In these variants (10 and 11 ), it increased by $14.5 \%$ at the $\mathrm{N}_{150}$ rate and by $8.8 \%$ at the $\mathrm{N}_{116}$ rate. A decrease in nitrogen removal was recorded with the urea application at a rate of $300 \mathrm{~kg} / \mathrm{ha}$ before sowing (variant 3 ) and in two doses: in the germination and tillering phases (variant 5) - by 11.2 and $9.8 \%$, respectively, as well as at $225 \mathrm{~kg} / \mathrm{ha}$ of UTEC (var. 7) - by $7.5 \%$. With all 
other schemes of nitrogen fertilization, only a weak tendency towards a decrease in nitrogen removal was noted. With the exception of the urea application in one step (variant 3 ), all schemes for the use of nitrogen fertilizers provided an increase in the yield removal of the element with grain (by 1.8-24.6\%) and a decrease - with by-products (by 6.5$32.8 \%$ ). Replacement of urea by UTEC urea leads to a reduction in nitrogen consumption for the formation of 1 centner of rice grain by $2.3-12.0 \%$. When it is applied before sowing and in one or two additional top dressings, the nitrogen utilization from the fertilizer increases by $11.0-21.8 \%$.

Yield removal of phosphorus increased by 6.1-21.0, with the introduction of UTEC carbamide before sowing and in germination phase (variants 8, 9), as well as in three doses - before sowing and in germination phase with UTEC carbamide and the second top dressing with urea (variant 10,11). The removal increased mainly due to the alienation with grain. The consumption of phosphorus for the formation of 1 centner of rice grain with all the schemes of using nitrogen fertilizers decreased by 3.7-7.4\%. The exceptions were variants with three-fold application of nitrogen fertilizers - UTEC before sowing and during germination phase, urea - in the tillering phase (variants 10,11), in which the phosphorus consumption for the formation of the yield was the same as that with the traditional rice fertilization system. UTEC application before sowing and in the germination phase (var. 8-11) indirectly, through an increase in the phosphorus demand of plants provided with a large amount of nitrogen, contributes to an increase in the phosphorus utilization from fertilizer by $6.2-21.3 \%$

\section{Conclusion}

When growing rice on the meadow soil of the rice irrigation systems of Krasnodar region, it is necessary to give preference to UTEC carbamide when applying nitrogen fertilizer at a full rate in one step, when it is not possible to carry out top dressing; it is not advisable to postpone the pre-sowing application of UTEC carbamide in top dressing (the probability of a decrease in rice yield in case of a delay with top dressing in the germination phase is not excluded); the second top dressing with UTEC carbamide is less effective than that with urea; when urea is replaced with UTEC carbamide and the recommended application rate is reduced by $20 \%$, the yield is comparable to that under the traditional scheme and rate of urea application; The following fertilization system is most effective: before sowing - ammophos $100 \mathrm{~kg} / \mathrm{ha}\left(\mathrm{N}_{12} \mathrm{P}_{52}\right)+$ UTEC carbamide $120 \mathrm{~kg} / \mathrm{ha}\left(\mathrm{N}_{55}\right)$; 1st top dressing (germination) UTEC carbamide $100 \mathrm{~kg} / \mathrm{ha}\left(\mathrm{N}_{46}\right)$; 2nd top dressing (tillering) - urea $80 \mathrm{~kg} / \mathrm{ha}\left(\mathrm{N}_{37}\right)$.

\section{References}

1. A. F. Bouwman, L. J. M. Boumans, N. H. Batjes. Global Biogeochem Cycl., 16(2), doi: https://doi.org/10.1029/ 2000GB001389, (2002).

2. H. Cantarella, D. Mattos, J. A. Quaggio, A. T. Rigolin, Nutr Cycl Agroecosys, 67(3), 21523, (2003).

3. H. Nitrogênio Cantarella. In: R. F. Novaes, A. V. V. Hugo, N. F. Barros, R. B. Cantarutti, J. C. L. Neves, editors. Fertilidade do Solo, (Viçosa: Sociedade Brasileira de Ciência do Solo, 2007).

4. H. Cantarella, P. C. O. Trivelin, T. L. M. Contin, et al., Sci Agric, 65(4), 397-401, (2008).

5. M. E. Trenkel, Slow- and controlled-release and stabilized fertilizers: an option for enhancing nutrient use efficiency in agriculture. 2nd ed., (Paris: IFA - Intl. Fertilizer Industry Association, 2010). 
6. S. H. Chien, L. I. Prochnow, H. Cantarella, Adv Agron, 102, 267-322. (2009).

7. M. A. Tabatabai, Soil. Biol. Biochem, 9(1), 9-13, (1977).

8. W. H. R. Shaw, J. Am. Chem. Soc., 7, 2160-3, (1954).

9. S. Benini, W. R. Rypniewski, K. S. Wilson, S. Mangani, S. Ciurli, J. Am. Chem. Soc., 126, 3714-5, (2004).

10. S. Kiss, M. Simihaian, Improving efficiency of urea fertilizers by inhibition of soil urease activity, (Doordrech: Kluwer Academic Publishers, 2002).

11. A.Kh. Sheudzhen, T.N. Bondareva, P.N. Khachmamuk, N. S. Galay, M.A. Perepelin, Rice growing, 2(47), 44-53, (2020).

12. E.V. Arinushkina, Guidelines on soil chemical analysis (M.: MSU, 1970).

13. F.Kh. Khaziev, Soil enzymology methods (M.: Science, 2005).

14. A.Kh. Sheudzhen, T.N. Bondareva, Methods of agrochemical research and statistical evaluation of their results (Krasnodar: KubSAU, 2015).

15. H. Cantarella, R. Otto, J. Rodrigues Soares, A. Gomes de Brito Silva, J. of Advanced Research, 13, 19-27, (2018).

16. K.Sh. Kazeev, S.I. Kolesnikov, Soil biodiagnostics: methodology and research methods (Rostov-on-Don: Publishing house of Southern Federal University, 2012).

17. D.G. Zvyagintsev, Soil studies, 6, 48-54, (1978). 